\title{
Addressing fragmentation in the South African renewable energy governance effort - lessons to be learnt from France
}

\author{
Romain Mauger ${ }^{1,2 *}$, Michelle Barnard ${ }^{1}$ \\ 1 Faculty of Law, North-West University, Potchefstroom Campus, Private Bag X6001, Potchefstroom 2520, \\ South Africa \\ 2 Faculty of Law, University of Montpellier, 39 rue de l'Université, 34060 Montpellier Cedex 2, France
}

\begin{abstract}
The drive towards increased renewable energy generation and its application in South Africa are codified in a variety of policy documents and pieces of legislation, which together embody the national renewable energy legal framework. In many instances these legal instruments differ in terms of the nature of the field of law influencing their objectives and the governmental department of their origin. This situation is generically labelled as fragmentation and is widely seen as a hindrance to the achievement of the Constitutional objective of promoting sustainable development in South Africa. By necessary implication, integration is proposed as the solution to fragmentation and it is in this regard that this study puts forward the French approach to legal and institutional integration as a possibility for South Africa. The study presents the French energy
\end{abstract}

transition legal framework for consideration by the South African legislature as a potential roadmap towards a more holistic and integrated renewable energy governance effort. In pursuing this objective, the study discusses the suitability of the French approach in the South African context and concludes that a hybrid of the French governance framework could fruitfully be applied locally.

Keywords: legal framework; energy transition; legal and institutional integration; energy law; environmental law

Journal of Energy in Southern Africa 29(1): 1-10

DOI: http://dx.doi.org/10.17159/2413-3051/2018/v29i1a1661

Published by the Energy Research Centre, University of Cape Town ISSN: 2413-3051 http://journals.assaf.org.za/jesa

Sponsored by the Department of Science and Technology

\footnotetext{
* Corresponding author: Email: r.j.g.mauger@rug.nl
} 


\section{Introduction}

The aim of the research undertaken is to put forward recommendations on how recent French legal and institutional developments in the field of renewable energy may be applied in facilitating a less fragmented approach to renewable energy regulation in South Africa. The methodology to be followed is, primarily, a literature study of the legal and institutional frameworks of France and South Africa, combined with some legal comparison between them.

The primary reason for undertaking the comparative portion of the research supporting this article is to attempt to improve the current South African approach to renewable energy regulation. Considering that renewable energy regulation in South Africa is characterised by horizontal legal and institutional fragmentation and that this fragmented approach hinders the sustainable development of renewable energy resources in the country, the need for a more integrated approach is evident. To put forward salient recommendations as to how this transition to integrated renewable energy regulation could and should take place it is necessary to identify a viable comparable legal counterpart. In this respect the French legal and institutional framework has been chosen for two main reasons: first, the similarity between the French and South African electricity production mixes, both relying massively on a single energy source (nuclear fission for France and coal for South Africa) and on a dominant player in electricity production; and, secondly, recent developments in holistic renewable energy regulation in France.

Undertaking a combined literature and comparative legal study between two distinct national legal frameworks requires that the scope of the study is properly delimited. While mention is made of the legal instruments as well as the institutional structures that regulate renewable energy in South Africa, these topics are not discussed in-depth. The focus is on identifying fragmentation within the South African renewable energy regulatory framework as a primary challenge to sustainable renewable energy development in the country, and the potential exemplary role France could play. Regarding France, the study focuses on the institutional and legal developments underlining the willingness to place renewable energy governance under a single department and to enhance their legal regime through a single flagship legislative act.

The discussion begins by contextualising the current South African energy situation, as background to a discussion of the legal and institutional framework regulating it. Then the fragmentation characterising the South African renewable energy regulation effort will be analysed against the backdrop of the concept of fragmentation, both institutional and legal. An exposition of the French elec- tricity context and institutional and legal landscape pertaining to renewable energy will follow. In conclusion, the French approach to renewable energy integrated policy building will be proposed as a possible way to develop integration in South African renewable energy regulation.

\section{Fragmentation in the South African renewable energy governance framework 2.1 Contextualising the South African energy situation}

The current energy situation in South Africa is dominated by the burning of fossil fuels, with coal the predominant energy source. The combustion of coal provides for $77 \%$ of South Africa's primary energy needs with the hegemonic public utility, Eskom, relying on coal-fired power stations to produce $90 \%$ of its electricity. The current energy situation is unlikely to change significantly in the next two decades owing to challenges related to issues of cost, the speed at which lower-carbon energy options can be established on a scale that can guarantee the country's baseload needs, and the impact such a shift is set to have on job creation and income generation (National Climate Change Response Green Paper, 2010). These challenges notwithstanding, several national policy documents clearly mandate the shift to a lower-carbon energy sector, with this shift taking the form of increased renewable energy generation and consumption. The origin of the legal mandate for increasing the generation capacity of renewable energy in South Africa is in the White Paper on the Energy Policy of the Republic of South Africa of 1998, which states that an equitable level of national resources must be invested in renewable technologies (paragraph 7.7). The subsequent White Paper on Renewable Energy of 2004 set the country's renewable energy target at 10000 GWh of annual energy generation by 2013. It furthermore highlighted the importance of developing an effective legislative system to promote the introduction of renewable energy while ensuring environmental protection (paragraph 7.2.2). These policy documents paved the way for the National Energy Act 34 of 2008, which states that the increased generation and consumption of renewable energy will be an important contributory factor towards attaining the objective of sustainable development (Section 2). It stresses the need to formulate an integrated and sustainable energy plan that focuses on issues such as the security of supply; economically available energy sources; affordability; universally accessible, free basic electricity; social equity; employment; the environment; international commitments; consumer protection; and the contribution of the energy supply to socio-economic development (Section 6(2)). In 2012 the Draft Integrated Energy Plan (DIEP) was published by the Department of Energy. It established the objec- 
tive of increasing the ratio of renewable energy to $10 \%$ of total energy output by 2030 , and stated that the target of $10 \%$ is to be maintained as a minimum from 2031 onwards (Section 3). The aim of the DIEP, which stresses the importance of an integrated approach to energy planning and regulation, is to provide a long-term vision of how energy can be optimally used as a mechanism for South Africa to remain competitive. It defines an integrated approach to energy planning and regulation as one that ensures alignment between the various existing sectors with an interest in energy generation and distribution (Section 1), but is vague on how this alignment is to be achieved.

Mindful of the focus placed on integrated energy planning and regulation by Act 34 of 2008 and the DIEP respectively, the present state of the South African renewable energy legal and institutional framework raises concern. The legal framework consists of various pieces of legislation and policy documents, cutting across a wide range of matters such as pricing and licensing requirements (Renewable Energy Feed-in-Tariff Regulatory Guidelines of 2009); procurement (Renewable Energy Independent Power Producer Procurement Programme of 2011); the mitigating effects of the implementation of renewable energy (MediumTerm Risk Mitigation Project for Electricity in South Africa 2010-2016; Integrated Resource Plan for Electricity 2010 - 2030; Biofuels Industrial Strategy for the Republic of South Africa of 2006; National Climate Change Response Green Paper of 2010 and National Climate Change Response White Paper of 2011); the establishment of a national energy regulator (National Energy Regulator Act 40 of 2014); and fiscal aspects such as tax and revenue (Carbon Tax Draft Bill of 2015). Furthermore, at the institutional level, various sectors such as water, agriculture, forestry, and transport are directly or indirectly linked to the generation and distribution of renewable energy in South Africa. The legal frameworks regulating these sectors are in most cases not aligned - a situation which contributes directly to exacerbating the existence and effects of legal and institutional fragmentation. Kotzé (2006) states that 'fragmentation of the environmental governance effort leads to unsustainable results in terms of effective and adequate service-delivery by government'. This study supports this view, and hypothesises that addressing the fragmentation prevalent in the environmental governance effort pertaining to renewable energy in South Africa is crucial to promoting a sustainable energy future. This hypothesis highlights the inherent interrelationship between environmental governance on the one hand and renewable energy regulation on the other. The legal frameworks of both fields should aim to promote sustainable development, as mandated by Section 24 of the Constitution of the
Republic of South Africa, 1996. While this mandate is clear and certain, its practical fulfilment is hampered to a large extent by the dual and competing objectives of the two fields of law. While environmental law aims to promote the protection and conservation of the environment and prevent pollution, energy law aims to facilitate economic growth through the generation and application of energy from natural resources. Energy law is economic in both nature and focus, while environmental law tends to aim to constrain economic activities that impede environmental objectives (Davies 2009). The procurement of energy sources in South Africa is a case in point, with the procurement of renewable energy happening alongside the unhindered procurement of additional fossil-based and nuclear energy. This has the practical effect of locking in energy technologies that environmental regulation aims to dislodge. Given the historically different objectives of the fields of energy and environmental law, one must not be surprised by the fragmentation presently characterising the two fields of law (Du Plessis 2015; Nel 2015; Musango et al. 2011).

\subsection{Institutional fragmentation}

Institutional fragmentation may be either vertical or horizontal. 'Vertical fragmentation' refers to the non-alignment of the practices of the national, provincial and local spheres of government. The South African government consists of three separate spheres, namely the national (parliament, president and national executive), the provincial (premiers, provincial legislatures and executive councils) and the local (municipalities) (Chapters 4-7 of the Constitution). These three spheres act under the umbrella of the provisions of the Constitution and may formulate and implement policy and legislation according to their separate Constitutional mandates. The laws and policies they enact must always conform to the rights and values expressed in the Constitution. Seeing that the current South African renewable energy legal framework consists almost exclusively of national laws and policies, vertical fragmentation is not identified as a challenge. 'Horizontal fragmentation' pertains to the activities of, in this case, environmental and energy departments or line functionaries within each sphere (Kotzé 2009). Of specific relevance to the discussion at hand is horizontal fragmentation within the context of the regulation of renewable energy provision. Parties to horizontal fragmentation in the renewable energy structure include (but are not restricted to) the Department of Water and Sanitation; the Department of Energy; the Department of Agriculture, Forestry and Fisheries; the Department of Mineral Resources; the Department of Environmental Affairs; and the Department of Transport. The legal instruments originating from these departments comprise the 
South African renewable energy legal framework a framework which is as fragmented as the institutional landscape it emanated from.

\subsection{Legal fragmentation}

Applying the definitions of horizontal and vertical legal fragmentation as provided by Kotzé (2006), it becomes apparent that the South African energy legal framework (within which renewable energy policy exists) is primarily fragmented along the horizontal line. This much is evident, considering that existing energy laws were drafted with the regulation of a handful of specific energy sources in mind: coal, petroleum, gas and nuclear. A further contributing factor to this regulatory disjuncture comes in the form of environmental laws and policy documents also containing reference to the manner in which renewable energy sources are to be regulated (Glazewski et al. 2012; Du Plessis 2015). This 'disparate set of laws' was listed by Glazewski in 2006 to include the Mineral and Petroleum Resources Development Act 28 of 2002; Electricity Act 41 of 1987; Gas Act 48 of 2001; Gas Regulator Levies Act 75 of 2002; the National Energy Regulator Act 40 of 2004; National Environmental Management Act 107 of 1998; National Water Act 36 of 1998; the National Air Quality Act; and the National Waste Management Act (Glazewski 2006). This means that the horizontal fragmentation characterising the regulation of renewable energy in South Africa relates not only to different laws pertaining to different energy sources but indeed to entirely different fields of law.

Murombo (2015) defines the fragmentation of renewable energy regulation in the South African context as a lack of coordination and synchronisation of the legislation, institutions and sectors that ideally should be intertwined'. He views integration - both legal and institutional - as the obvious remedy for fragmentation and believes such integration may take the form either of enacting a single piece of legislation governing all aspects of a specific topic or of creating 'super-regulatory institutions' endowed with regulatory authority. While legal integration within South African environmental law has steadily progressed via framework legislation (National Environmental Management Act 107 of 1998 - NEMA), this reform of environmental law has not been fully harmonised with legal developments in the energy sector (Murombo 2015). At the substantive level, the development of energy and environmental legislation has for the most part taken place separately, mainly due to energy and the environment being treated as institutional silos. This contributes to an absence of integrated planning, as well as the drafting and implementation of renewable energy legislation that reflects environmental law principles. A practical example can be found in the Department of Environmental Affairs and the Department of Energy not having (until very recently) the common objective of promoting the sustainable use of natural resources, including those resources to be harnessed in the generation of renewable energy (Murombo 2015).

The foregoing discussion has highlighted the dualistic nature of the horizontal legal fragmentation characterising the regulation of renewable energy in South Africa. The duality in the fragmentation results from different energy sources being legislated by different and disjointed pieces of legislation and energy law and environmental law not being synchronised. This does little, if anything, to facilitate an integrated approach to the development and application of renewable energy in South Africa. To address this situation, the current research proposes to follow the direction provided by Murombo and suggests that the creation of a single regulatory institution with the authority to draft legislation that integrates environmental law into renewable energy law will remedy the current fragmentation. In this regard, it is proposed that recent legal and institutional developments pertaining to integrated renewable energy governance in France be considered as a viable option for South Africa.

\section{The French situation, an energy transition framework law under a single department 3.1 Contextualising the French energy situation}

The French energy situation is relatively close to the one of South Africa, with some similar fundamental drivers. The primary point of overlap is in both country's electricity mixes being dominated by a specific energy source. In France, nuclear electricity represents around $75 \%$ of the total power produced, even if this proportion varies each year, following the nuclear power plants availability factor as well as the output of other energy sources, such as hydroelectricity (Réseau de Transport d'Élect-ricité (RTE) 2017). The South African energy mix (as indicated above) is dominated by coal-based electricity. As with coal, nuclear electricity production is not very flexible. To vary its load takes time and entails high costs, which makes these two fuels good baseload but poor back-up providers (International Renewable Energy Agency (IRENA) 2015). The second point is that, historically, France and South Africa both have one predominant public electricity company responsible for electricity production, transportation and distribution. This was more the case in France 20 years ago. Today, following the energy liberalisation process responding to European Commission pressure, the electricity sector has been unbundled, with the activities of Electricité de France (EDF), the formerly publicly owned and monopolistic French utility, separated. Electricity transportation and distribution activities are now out of EDF's scope, although it still fully 
owns the new transmission system operator and distribution system operator. EDF itself has been a private company since 2004 (Electricity and Gas Public Service and Companies Act 2004-803 of 9 August 2004, Section 24) even though the state still holds $84.5 \%$ of its shares (Agency of State's shares). In 2017, EDF was still playing a major role in the French electricity production mix, as it owns all of the nuclear facilities, more than half of the installed hydroelectric capacity and multiple other thermal facilities, as well as having a significant wind and solar capacity.

The situation in France and South Africa can then be seen as quite similar, both because of the strong reliance on a single energy source for electricity generation, and because there is one strongly dominant company or utility in the electricity market.

\subsection{Institutional integration: One department to rule them all}

As in the South African system, there is vertical fragmentation in France, but in a very different and less deep way. Instead of the three separate spheres of government (national, provincial and local), France, historically marked by centralisation, has only the national (president of the Republic, government and parliament) and the local ones (regions, departments, municipalities and their associations, all under the name of local authorities) (Sections 5 to 33 and 72 to $75-1$ of the Constitution). Both spheres have a role to play in energyrelated issues, the most basic being potentially that the provisions enacted by the state need to be locally promoted and enforced by local actors (especially local authorities) to be successful. As to horizontal fragmentation, however, the situation differs from the South African one, as explained below.

The first Ministry of Environment in France was created in January 1971 - in fact a deputy ministry attached to the prime minister (Decree 71-94 of 1971). From this year up until 2007, environment and energy were kept apart except when dealing with industrial disasters and their consequences. Hydroelectricity (still the first source of renewable electricity in France in 2017) was then perceived as a tool to produce abundant and cheap energy for economic development more than being developed for being a renewable source and potentially environmentally friendly. There were then no reasons for considering energy as linked to environmental policy more than to industrial policy. But the emergence of the climate change issue and the important role played by energy production and consumption in greenhouse gas emissions (IPCC 2014) finally led to the two being placed under a single authority. It was supposed that the creation of a Ministry in charge of Ecology, and Sustainable development and planning translates the willingness of the
Government to integrate the sustainable development goals into the formulation and the implementation of the public policies' (Laville 2010). That is why, in 2007, the newly elected president Nicolas Sarkozy decided to create a 'super-ministry' of sustainable development, aggregating the three major areas of environment, energy and transportation (Decree 2007-995 of 2007). From 2010 to 2012, however, this ministry lost energy but gained housing (Decree 2010-1443 of 2010).

From 2012 to 2017, during the mandate of François Hollande, the concept of a super-ministry combining at least the authorities on environment and energy was reinstated (Decree 2012-772 of 2012 and Decree 2014-401 of 2014), crowning their institutional integration. Lastly, the new president Emmanuel Macron reproduced this scheme with the Ministry for an Ecological and Inclusive Transition (Decree 2017-1071 of 2017), allowing this integration of environment and energy policies to take root in the institutional history of France.

During the making of the 2015 energy transition flagship act (analysed later), from the public participation process (in 2013) to the Parliamentary debates on the draft law, the steering political force was the Ministry of Ecology, Sustainable Development and Energy. This department had authority over sustainable development, the environment, green technologies, energy transition, energy tariffs, the climate, industrial security, transportation and infrastructure, but also the sea, and the prevention of natural and technological risks (Decree 2012-772 of 2012 and Decree 2014-401 of 2014). The only jurisdictions which were missing for this to be a complete set of renewable energy functions were housing and town planning, which were assigned to the Ministry of Housing and Territorial Equality (Decree 2014-414 of 2014).

The existence of this extensive ministry gave the executive the tools with which to organise a multisectorial process to change the face of environmental and renewable energy regulations in France.

\subsection{Legal integration: One flagship act to address every renewable energy issue}

Until 2011, there was no Energy Code in France, meaning that energy law was an aggregation of provisions coming from a succession of acts dating back to the earliest in 1906, and a diversity of regulations, with many of these legal elements codified in more than 20 different codes, creating a deep fragmentation in energy law (Sablière 2011). Even the creation of this code was not enough to get back some core elements of modern energy law like parts of the renewable energy facilities development or of nuclear energy safety. Notwithstanding, steps have been made in the recent past to build a kind of framework law to provide in one piece of legislation the frame for energy transition. This takes its roots 
into a new environmental law-making process, discussed below.

In 2007, in parallel of the creation of the "superministry' in charge of the environment and energy, a wide public participation process, named Grenelle de l'Environnement (the term 'Grenelle' refers to the agreement signed in the Rue de Grenelle in Paris, which brought the 1968 social upheaval to an end), was launched. Aimed at opening the discussion on many environmental matters before the parliamentary debate starts and to reach an agreement on a draft law supported by different sectors of the society, the process addressed the ecological crisis as a global issue, requiring the identification of measures for environmental protection but also regarding transportation, town planning and energy, amongst others. It arose from the idea that the best way to create an efficient legal framework on this question was to build a five-party governance structure, including representatives of government, local authorities, trade unions, the employers' federation and NGOs. The work of this multiparty body gave birth to two broad-scale environmental laws: the Grenelle I Act 2009-967 of 2009 and the Grenelle II Act 2010-788 of 2010. The first of these concerned objectives, and the second had to do with implementation and the fulfilment of the commitments made in the first.

More recently, on 17 August 2015, the Energy Transition towards Green Growth Act 2015-992 of 2015 was approved. This act is the result of an elaboration based on the Grenelle process with the addition of sixth and seventh partners to the consul- tation process, namely parliamentarians and representatives of civil society associations. This new public debate was named National Debate on Energy Transition (NDET) (Synthèse des travaux du débat national sur la transition énergétique de la France 2013). The institutionalisation of a public debate on matters of the environment and renewable energy is aimed at involving every citizen in the decision-making process and thus increasing the legitimacy of the decisions taken by the Parliament at the end of the day. In the Grenelle de l'Environnement as well in the NDET, it ended up with a major flagship act. For the Grenelle, on environmental and related issues, for the NDET, on the energy transition.

The development of one all-encompassing law, which would be called a framework law in the South African system, offers people the opportunity to understand how environmental and energy concerns are interrelated. It is supposed to make it easier for them to understand that it is no longer possible to believe in solving environmental problems without addressing the energy, construction, transportation and farming fields, or to realise the energy transition without tackling these aspects, amongst many others. It also offers the possibility of giving predictability to economic actors, with a set of short-, medium- and long-term objectives, in theory accompanied by effective tools for their accomplishment. Moreover, it is meant to make for easier readability, as people would know that all of the important provisions for the environment or the energy transition are in a single flagship piece of

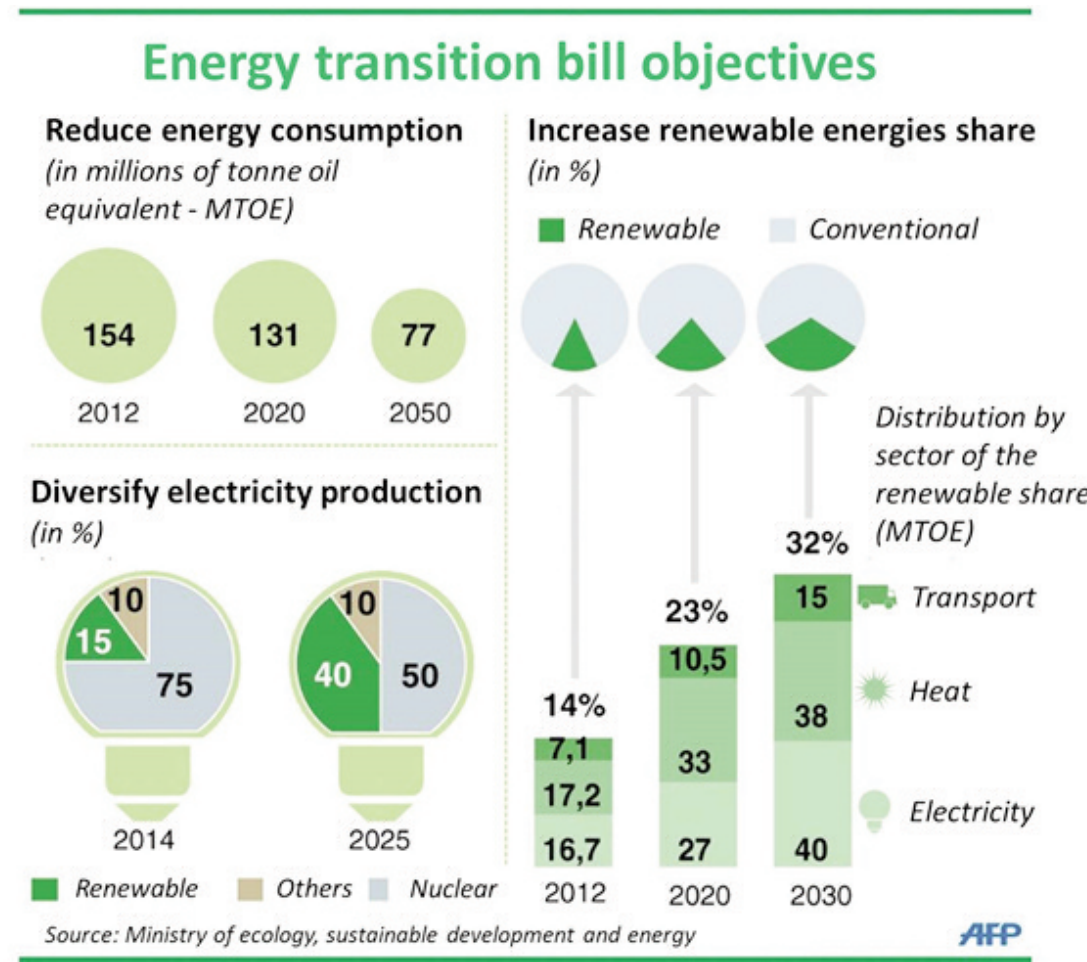

Figure 1: Energy Transition Act objectives (http://www.rtl.fr/actu/politique/la-transition-energetiquelargement-adoptee-a-I-assemblee-7774823569). 
legislation that should stay for years. But there are drawbacks as well, one of the most important of which is the size that these acts usually reach when trying to provide a legal basis to the broad results of the public debate. The Grenelle II act (the 'toolbox' law) thus accumulated not fewer than 257 sections, causing a loss of readability and therefore of accessibility to the public. The Energy Transition Act had 215 provisions, without however providing a clear, complete and self-sustained energy transition legal framework.

Regarding the Energy Transition towards Green Growth Act specifically, the text, which is organised under eight headings, provides measures regarding construction, transportation, circular economy, renewable energy and energy consumption, as well as nuclear energy, public information, and the simplification of some administrative procedures. Consequently, the text resorts in the category of framework law for the diversity of its themes without, however, providing the panorama that can be found, for example, in the NEMA in South Africa.

The main concerns of the law have to do with energy production and consumption. Figure 1 shows some graphic representations of those objectives. Qualified as 'the first Act truly displaying a vision and expressing an ambition for the energy sector since the liberalisation started after the Single European Act (1986)' (Barthelemy et al. 2015), its objectives are more ambitious than those fixed at the European Union level in the 2030 framework for climate and energy policies (European Union 2014). For example, while the European agreement, signed in 2014, requires a $27 \%$ share of renewable energy in the gross final energy consumption (European Council 2014), the first article of the energy transition text provides for a share of $32 \%$.

In the following paragraphs, this study focuses on electricity matters and especially on the thorny question of the reduction of nuclear energy's share in the electricity mix. This question, essential for the integration of a higher share of renewables into the mix, highlights some of the challenges that the legal integration displayed by the Energy Transition Act does not allow to fix by itself.

Undoubtedly, this Act was envisaged as a symbol of France's commitment to limit its emissions of greenhouse gases and push for renewable energy development in France and worldwide to prepare for the Conference of Parties (COP21) of the United Nations Framework Convention on Climate Change (UNFCCC) which took place in Paris in December 2015.

To achieve the major diversification of the energy sources and reduce the nuclear energy share in electricity production from $75 \%$ to $50 \%$ at the same time (see Figure 2 for the historical developments in electricity production) article 187 of the Energy Transition Act caps the total installed nuclear capacity at $63.2 \mathrm{GW}$ (existing installed capacity).

The tools provided by the 2015 act are widely judged by observers, especially NGOs, to be insufficient to reduce the nuclear share under discussion (Garric 2014). The core problem is that the state cannot legally order the supplier (EDF) to shut down one of its facilities for other than safety reasons (Section L. 593-23 of the Environment Code). That is so even in this case, where the state holds $84.5 \%$ of the shares of the holding company, EDF. That could constitute an undue use of its majority powers (Gossement 2012) and would at least lead to the state's having to pay millions of euros to other shareholders. In an attempt to circumvent the problem, the Energy Transition towards Green Growth Act has capped the total installed capacity, and the aforementioned article 187 forces the main operators in the sector to 'establish a strategic plan, introducing the measures it intends to take in order to meet the supply security and electricity production diversification objectives fixed in the multiannual energy scheduling'. If this strategic plan does not conform to the energy transition objectives or not accord with the multi-annual schedule (Section 176 of the Energy Transition Act) elaborated by the government, at the end of the day the

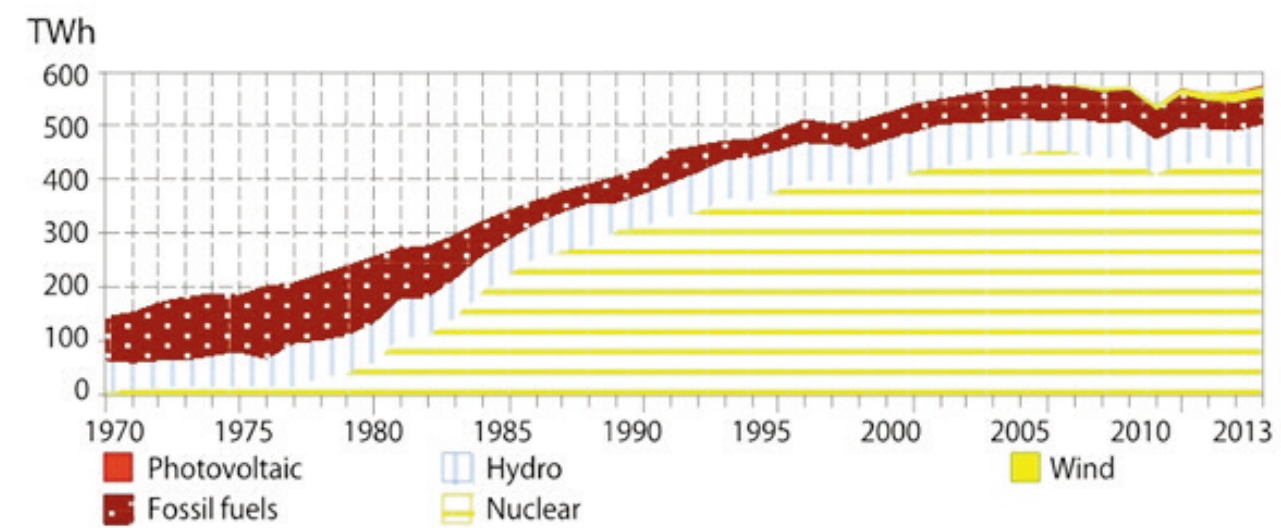

Figure 2: Power generation in France since 1970 (http://blog.iass-potsdam.de/2015/05/energytransition-france-following-in-germanys-footsteps). 
state can oppose any investment decision.

The negative aspect of this measure is that the government has not acquired the authority to really manage electricity production. All it can do is oppose decisions that run counter to policy. Yet, this competency is necessary to reach the other objectives of the law, and especially the energy consumption reduction goal (see Figure 1). Without this energy consumption reduction objective, the simple fact of extending the life-span of the existing nuclear reactors and/or replacing the decommissioned ones, as soon as the total capacity remains under the cap fixed by the law, could have been a way to reach the $75-50 \%$ of nuclear energy in electricity consumption by 2025 goal. An increase in total electricity consumption would have then been needed to gradually reduce the share of nuclear electricity. But the projections in France foresee a diminution in electricity production for the short-tomedium-term future (RTE 2016).

Moreover, this issue is not the only one related to the Energy Transition Act. For example, it has also been used by some parliamentarians in support of their attempts to oppose the development of wind farms, thus increasing the legal uncertainty to which developers are presently subject. (Section 139 of the Act empowers the prefect to increase the mandatory distance between wind turbines and dwellings after the performance of environmental impact assessments, when it is too late in the development process to change all the maps and studies that have gone into the application for approval).

\section{Discussion}

The developments discussed above allow some lessons to be drawn from the French experience, and a consideration of the advantages and otherwise in the eventuality of an adaptation of that strategy to the South African situation. First, the horizontal integration of the institutions seems to have been a success, allowing the establishment of a single authority able to insert sustainable development and renewable energy deployment into the other fields that are impacted by these policies or that could have an impact on these matters. Transportation, housing, farming and forestry are some of these major policy fields directly related to energy issues. Their integration in France (or of at least most of them) into a single ministry facilitated the communication inside the administration, but also communication with the public, fostering the steering of a wide public debate which led to the adoption of flagship acts in matters of the environment and energy. Secondly, and consequently, this institutional horizontal integration helped writing silo-breaking acts, thus leading to progresses in legal integration. The discussed acts (Grenelle I and II, the Energy Transition towards Green Growth Act) testify to a more integrated law-making process, supposed to provide better quality texts combining from the beginning the multiple legal fields required for a coherent, all-encompassing action. They are also seen as more understandable and useful for the recipients, in this way potentially leading to an improved law enforcement.

This legal integration cannot, however, be claimed as a complete success in France, as many aspects are still not integrated into the energy transition act; nor does it provide the necessary tools to reach the displayed objectives. These elements show that if the theoretical scheme for an integrated law-making in France regarding the transition towards renewable energy has been understood, the practical application faced headwinds and did not lead to the advent of an integrated legal framework in this matter.

With the foregoing in mind some preliminary comments may be made as to the practical implementation of the French approach to legal and institutional integration in South Africa. The way the French government has addressed the issue of a fragmented renewable energy institutional framework by combining distinct government departments into a single authority should be the first step towards a more integrated governance effort in South Africa. The practical effect of this institutional reform would be to combine national government departments that are currently operating independently and align their different mandates and objectives. If the French approach is to be followed, South African departments such as Water and Sanitation, Energy, Agriculture, Forestry and Fisheries, Mineral Resources, Environmental Affairs, and Transport would be affected. The same is also true of the legal integration route followed by the French. It is advisable (and this will be elaborated upon in the next section) that the content of the French renewable energy laws be considered for inclusion in the South African legal framework. Moreover, the objective of integrated energy planning as outlined in the DIEP, Integrated Resource Plan (IRP) and National Development Plan (NDP) should inform the process of legal mainstreaming in much the same way as was the case in the French context. This means that existing laws and policies be amended and renewable energy considerations be included or mainstreamed into the texts in order to have the desired integration effect.

\section{Conclusions and recommendations}

While some progress has recently been made in developing a renewable energy legal framework in South Africa, institutional fragmentation remains a major impediment to fully realising the country's energy reform objectives. A host of different governmental departments participate directly and indirectly in the regulation. France, for its part, has changed the way public policies in such matters are 
arrived at and implemented, chiefly by assigning all environmental and energy issues to a single governmental authority. While developing an integrated view of energy generation and use in a global context, including the integration of renewable energy into the power production mix, it has been able to take into account such various issues as transportation, housing, environmental impacts, and local employment. The involvement of mass public participation in the process that led to the evolution of that new policy was also conducive to change in the public mind set about matters relating to energy production and use, and regarding the very lawmaking process. However, the state has created large legally-backed expectations and now has to stand by its commitment.

Recommendation 1: To address the existing institutional fragmentation in South Africa, a single governmental institution should be established, dealing specifically with all aspects of the implementation of an energy framework law, and therefore the regulation of renewable energy.

Recommendation 2: In order to address the legal fragmentation prevalent in renewable energy governance in South Africa, a framework law dealing specifically with renewable energy should be drafted, aiming to integrate the various policies and pieces of legislation relating to renewable energy into a single and coherent piece of legislation. This framework requires a careful approach to provide ambitious but achievable objectives underpinned by appropriate tools, unlike in the French case.

Recommendation 3: The South African government should build this renewable energy framework law through a wide public participation process (although this aspect has been little considered in this paper), garnering the expertise of civil society, business and relevant experts in this field, while simultaneously developing public goodwill towards the outcomes of the process. This measure could facilitate the proper enforcement of the act, as the informed citizens can act as watchdogs.

\section{References}

\section{French legislation}

Decree 71-94 of 1971. Décret n 71-94 du 2 février 1971 relatif aux attributions du ministre délégué auprès du Premier ministre, chargé de la protection de la nature et de l'environnement.

Decree 2007-995 of 2007. Décret n²007-995 du 31 mai 2007 relatif aux attributions du ministre d'Etat, ministre de l'écologie, du développement et de l'aménagement durables.

Decree 2010-1443 of 2010. Décret n²010-1443 du 25 novembre 2010 relatif aux attributions du ministre de l'écologie, du développement durable, des transports et du logement.
Decree 2012-772 of 2012. Décret n²012-772 du 24 mai 2012 relatif aux attributions du ministre de l'écologie, du développement durable et de l'énergie.

Decree 2014-401 of 2014. Décret n²014-401 du 16 avril 2014 relatif aux attributions du ministre de l'écologie, du développement durable et de l'énergie.

Decree 2014-414 of 2014. Décret n² 2014-414 du 16 avril 2014 relatif aux attributions du ministre du logement et de l'égalité des territoires.

Decree 2017-1071 of 2017. Décret n²017-1071 du 24 mai 2017 relatif aux attributions du ministre d'Etat, ministre de la transition écologique et solidaire.

Electricity and Gas Public Service and Companies Act 2004-803 of 9 August 2004. Loi n 2004-803 du 9 août 2004 relative au service public de l'électricité et du gaz et aux entreprises électriques et gazières, art. 24.

Environment Code. Code de l'environnement 2017, annoté et commenté, Dalloz, $20^{e}$ édition.

Energy Transition towards Green Growth Act 2015-992 of 2015. Loi n $2015-992$ du 17 août 2015 relative à la transition énergétique pour la croissance verte.

Grenelle I Act 2009-967 of 2009. Loi n 2009-967 du 3 août 2009 de programmation relative à la mise en œuvre du Grenelle de l'environnement.

Grenelle II Act 2010-788 of 2010. Loi n ${ }^{\circ} 2010-788$ du 12 juillet 2010 portant engagement national pour l'environnement.

\section{South African Legislation}

Electricity Act 41 of 1987. Government Gazette, 1 November 1987.

Gas Act 48 of 2001. Government Gazette, 21 February 2002.

Gas Regulator Levies Act 75 of 2002. Government Gazette, 15 January 2003.

Mineral and Petroleum Resources Development Act 28 of 2002. Government Gazette, 10 October 2002.

National Water Act 36 of 1998. Government Gazette, 26 August 1998.

National Environmental Management Act 107 of 1998 Government Gazette, 27 November 1998.

National Air Quality Act 39 of 2004. Government Gazette, 24 February 2005.

National Energy Regulator Act 40 of 2004.Government Gazette, 6 April 2005.

National Energy Act 34 of 2008. Government Gazette, 24 November 2008.

National Waste Management Act 59 of 2008. Government Gazette, 10 March 2009.

\section{Institutional documents}

Carbon Tax Draft Bill. 2015. Minister of Finance. Available at: https://cer.org.za/wp-content/uploads/ 2016/06/Carbon-Tax-Draft-Bill-2015.pdf Accessed February 2018.

Department of Minerals and Energy, 2007. Biofuels industrial strategy for the Republic of South Africa. Available at: http://www.energy.gov.za/files/esources/ renewables/biofuels_indus_strat.pdf(2).pdf. Accessed February 2018.

Department of Energy, 2010. Medium-term risk mitigation project for electricity in South Africa (MTRMPE- 
SA) 2010 - 2016. Available at: http://www.doeirp.co.za/content/medium_term_risk_mitigation_project_phase_1.pdf Accessed February 2018.

Department of Energy, 2011. Integrated Resource Plan for Electricity 2010-2030. Available at: http://www. energy.gov.za/IRP/irp\%20files/IRP2010_2030_Final_ Report_20110325.pdf Accessed February $20 \overline{1} 8$.

Department of Energy and Department of National Treasury, 2011. Renewable Energy Independent Power Producer Procurement Programme.

European Council 23 and 24 October 2014, Conclusions, 2030 Climate and energy policy framework, p. 5. Available at: http://www.consilium. europa.eu/uedocs/cms_data/docs/pressdata/en/ec/14 5397.pdf Accessed August 2017.

European Union, 2014. 2030 framework for climate and energy policies. Available at: http://ec.europa.eu/ clima/policies/2030/index_en.htm. Accessed July 2015.

Intergovernmental Panel on Climate Change (IPCC), 2014. Climate change 2014: Mitigation of climate change. 'Summary for Policymakers'. Figure SPM.2: 9. Available at: http://www.ipcc.ch/pdf/assessmentreport/ar5/wg3/ipcc_wg3_ar5_full.pdf Accessed November 2017.

International Renewable Energy Agency (IRENA), 2015. From baseload to peak: Renewables provide a reliable solution: 6. Available at: http://www.irena.org/ DocumentDownloads/Publications/IRENA_Baseload _to_Peak_2015.pdf Accessed July 2015.

National Climate Change Response Green Paper of 2010. Notice 1083 of 2010. Government Gazette, 25 November 2010.

National Climate Change Response White Paper of 2011. Available at: https://www.gov.za/sites/www. ov.za/files/national_climatechange_response_whitepa per_0.pdf Accessed February $201 \overline{8}$.

National Energy Regulator of South Africa (NERSA), 2009. Renewable Energy Feed-in-Tariff (REFIT). Regulatory guidelines. Available at: http://www .innovent.com.uy/site/content/legislacion/south_africa _renewable_energy_feed_in_tariff.pdf Accessed $\bar{F}$ ebruary 2018.

Réseau de Transport d'Électricité (RTE). 2016. Bilan prévisionnel de l'équilibre offre-demande d'électricité en France, édition 2016: 7. Available at: http://www. rte-france.com/sites/default/files/bp2016_complet_vf. pdf Accessed May 2017.

RTE. 2017. Bilan électrique 2016, Production, 'Le parc progresse de près de 1700 MW'. Available at: http:// bilan-electrique-2016.rte-france.com/production/leparc-de-production-national/ Accessed May 2017.

Synthèse des travaux du débat national sur la transition énergétique de la France. 2013. Available at: https:/www.ecologique-solidaire.gouv.fr/sites/default /files/Synth\%C3\%A8se\%20du\%20d\%C3\%A9bat\%2 Onational\%20sur\%20la\%20transition\%20\%C3\%A9n erg\%C3\%A9tique.pdf Accessed September 2017.

\section{Journal articles}

Barthelemy, C., Cloche-Dubois, C., Felizot, C., and Rubio, A.E. 2015. La loi sur la transition énergétique: déclaration d'intentions ou socle d'une transformation dirigée de l'économie française? Première partie. Droit de l'Environnement 11 (239): 388-397.

Davies, L.L. 2009. Alternative energy and the energyenvironment disconnect. Idaho Law Review (46): 473-506.

Du Plessis, W. 2015. Energy efficiency and the law: A multi-disciplinary approach. South African Journal of Science (111): 1-8. https://doi.org/10.17159/ sajs.2015/20130302.

Laville, B. 2010. Du Ministère de l'Impossible au Ministère d'Etat. Revue française d'administration publique (134): 277, 278.

Kotzé, L.J. 2006. Improving unsustainable environmental governance in South Africa: A case for holistic governance. Potchefstroom Electronic Law Journal (9): 75-118.

Kotzé, L.J. 2009. Environmental governance. In Paterson, A., and Kotzé, L.J. (eds) Environmental Compliance and Enforcement in South Africa: Legal Perspectives. South Africa: Juta.

Murombo, T. 2015. Regulating energy in South Africa: Enabling sustainable energy by integrating energy and environmental regulation. Journal of Energy and Natural Resources Law 33 (4): 320-348. https://doi.org/10.1080/02646811.2015.1089113.

Musango, J.K., Amigun, B., and Brent, A.C. 2011. Sustainable energy generation technologies in South Africa: Initiatives, challenges and policy implications. Energy and Environmental Research 1 (1): 126. https://doi.org/10.5539/eer.v1n1p124.

$\mathrm{Nel}, \mathrm{D} .2015$. Risks and barriers in renewable energy development in South Africa through independent power production. African Journal of Public Affairs 8 (1): 48-49.

Sablière, P. 2011. Un code en manque d'énergie. Actualité Juridique du Droit Administratif: 1427.

\section{Online resources}

Agency of State's shares, Agence des Participations de l'Etat. The public shares. Available at: http://www. economie.gouv.fr/agence-participations-etat/Les-participations-publiques Accessed July 2015.

Garric, A. 2014. Les moyens pour atteindre la transition énergétique ne sont pas au rendez-vous. Le Monde. Available at: http://www.lemonde.fr/planete/article/ 2014/06/18/les-moyens-pour-atteindre-la-transitionenergetique-ne-sont-pas-au-rendez-vous_4440415 3244.html_Accessed July 2015.

Glazewski, J. 2006. The legal framework for renewable energy in South Africa. Available at: http://www.un. org/esa/sustdev/sdissues/energy/op/parliamentarian_f orum/glazewski_re_sa.pdf. Accessed November $201 \overline{7}$.

Glazewski, J., Gilder, A., and Swanepoel, E. 2012. Carbon capture and storage (CCS): Towards a regulatory and legal regime in South Africa. Report for the Institute of Marine and Environmental Law and African Climate and Development Initiative. University of Cape Town, Cape Town. Available at: http://www.imel.uct.ac.za/usr/law/imel/downloads/CC S_Report.pdf Accessed November 2017.

Gossement, A. 2012. Fessenheim: il faudra bien une loi. Gossement Avocats. Available at: http:/www. arnaudgossement.com/archive/2012/10/21/fessenheim-il-faudra-bien-une-loi.html Accessed July 2015. 